\title{
LABOUR MARKUPS IN THE POLISH FOOD SECTOR
}

In the period 2000-2013 the Polish agro-food sector enjoyed a very dynamic growth. The research objective was to measure monopolistic markups based on labor input, which indicate the level of market power, with data and improved methodology proposed by Nekarda and Ramey [2013). The research object was the Polish food sector in the period 2002-2013. Taking into account overhead labor, CES production function and marginal wage different from average wage, six adjustments were used. Because of the corrections the average food sector markup increased from $17.7 \%$ of price in the baseline scenario to $67.9 \%$ of price when three corrections were implemented together. It appeared that the food sector markup in the analyzed period depending on the specification increased by 13.5 to $31.3 \%$. Moreover, markups in the analyzed period proved to behave counter-cyclically regarding the business cycle.

Keywords: markups, food sector

DOI: $10.15611 /$ aoe.2018.2.13

\section{INTRODUCTION}

Commonly, not only in Poland, the agro-food sector is regarded as one of the most regulated, traditional, extensive and of the strategic importance regarding national food security. In the period 2000-2013 the Polish agrofood sector enjoyed very dynamic growth. The value of the food production sold nearly doubled, which was mostly connected with entering the EU (Łopaciuk et al. 2014). In 2013 the export of Polish agro-food products amounted to EUR18.7 billion, constituting $12.5 \%$ of total Polish exports. Just in 2010 the three biggest capital groups generated $85.7 \%$ of revenues in oil manufacturing, $78.5 \%$ in brewing industry, $76.9 \%$ in the tobacco industry, $75.6 \%$ in potato production and $69.6 \%$ in production of sugar (Szczepaniak 2012). The risk is that such processes might have led to the non-competitive behavior of entities dominating in a certain branch, which can start using their market power during price fixing. Therefore, the research question is whether this rapid development of the Polish food sector was accompanied by a significant increase in the level of market power.

\footnotetext{
* Institute of Agricultural and Food Economics - National Research Institute, Warsaw.
} 
Church and Ware (2000) stated that market power is a firm's ability to profitably increase the price above the marginal cost, and Pindyck and Rubinfeld (2013) - that it is either a seller's or a buyer's ability to influence a product's price. The indicator of the market power is therefore the markup of price over marginal cost (Olive 2000). Because the available data typically include only average cost, researchers have used a variety of techniques to estimate the market power, e.g. a total cost function estimation, the price response to a change in costs, the New Empirical Industrial Organization, the stochastic frontier method, the game theory, the overall efficiency loss estimation, the single input margin (Tremblay and Tremblay 2012).

The occurrence of markups implies the decrease of the industry welfare defined as the sum of consumer and producer surpluses, and consequently the market's efficiency. In particular, the market power influence is measured by the deadweight loss, which is the welfare loss caused by the departure from the competitive equilibrium (Carlton and Perloff 2004). Therefore, in the case of an excessive market power in the Polish food sector, an appropriate competition policy should be applied. Carlton and Perloff (2004) distinguish three important policy areas regarding market power, i.e. international trade, antitrust law and policy, regulation and deregulation. Nevertheless, the optimal policy interventions need to be proceeded with a detailed analysis using the game theory and the mechanism design theory. In these fields, among other contributors, especially the paper by Tirole stands out (The Royal Swedish Academy of Sciences 2014).

In such a framework the purpose of this paper is to measure markups of price over marginal cost in the Polish food sector in the period 2002-2013 ${ }^{1}$ using methods based on the labor input (here called labor markups) proposed by Bils (1987), Rotemberg and Woodford (1999) and presented by Nekarda and Ramey (2013). It should be added, that the monopolistic markups in the Polish economy have been a matter of interest for the Polish researchers such as Gradzewicz and Hagemajer (2007a,b), Hagemajer and Popowski (2012), Gradzewicz et al. (2012), mostly because the markups behaviour has important implications for the conduct of monetary policy. Nevertheless, in none of these articles the labor markups in the food sector were calculated. Only Gradzewicz and Hagemejer (2007b) calculated the food sector markups, but they took advantage of the method based on the price response to a change in costs (Roeger 1995). The applied developments in the

\footnotetext{
${ }^{1}$ Due to the data availability, the earlier analysis was not possible.
} 
calculation of labor markups have not been applied either in the Polish literature of the subject so far. Moreover, the cyclicality of the labor markups with respect to the macroeconomic cycle will be measured using correlation analysis.

\section{METHODS OF LABOR MARKUPS CALCULATION AND DATA}

As highlighted by Samuelson and Marks (2009) it can be written that:

$$
M R P_{i}=M R \cdot M P_{i},
$$

where $M R P_{i}$ is a marginal revenue of production factor $i, M R$ is a marginal revenue, and $M P_{i}$ is a marginal product of production factor $i$. Because a profit maximization condition is: $M R=M C$, where $M C$ is a marginal cost, the optimal markup can be expressed as follows:

$$
\mu=\frac{P \cdot M P_{i}}{M R P_{I}}
$$

where $P$ is a price of a product. Consequently, marginal costs of increasing production by increasing any of the production factors should be equal. Rotemberg and Woodford (1999) stated that because of the fact that there are adjustment costs of hiring additional workers and capital stocks, whilst the adjustment costs of changing hours per worker are insignificant, it is the most common way of increasing production.

If the production function is as follows:

$$
Y=F(Z h N, \ldots) \text {, }
$$

where $N$ is a number of workers, $Y$ is an output, $Z$ is a labor-augmenting technology, $h$ is a number of hours per worker, and $W_{A}$ is an average hourly wage; from the first order condition for the cost minimizing firm choosing hours per worker we get:

$$
M C=\frac{W_{A}^{\prime} h+W_{A}}{F_{1}(Z h N, \ldots) Z},
$$

where $W_{A}^{\prime}$ is a derivative of average wage against $h$ and $F_{1}$ is a derivative of production function against effective labor $Z h N$ (Nekarda and Ramey 2013). Marginal cost of increasing production is a relation of marginal revenue of increasing hours per worker to marginal product per worker. 
In the baseline specification it is assumed that the production function is Cobb-Douglas (C-D), an elasticity of output with respect to hours $(\alpha)$ is constant and the observed average wage is an appropriate cost of hiring additional labor. Consequently, labor markups are expressed as follows:

$$
\mu_{A}^{C D}=\frac{P}{W_{A} /\left[\alpha\left(\frac{Y}{h N}\right)\right]}=\frac{\alpha}{s},
$$

where $s$ is a labor share calculated as a ratio of total compensation of labor (sum of: wages and salaries, social insurance, training, business travels, health care) to the net revenues from the products sold adjusted by the change in inventories and indirect taxes (sum of excise tax, property tax, tax on means of transport, non-deductible value-added tax), whereas $\alpha$ is received from the generalized C-D production function in the form proposed by Basu and Kimball (1997) taking into account the costs of four production factors, where capital is calculated as a sum of intangible and capital assets multiplied by the sum of depreciation ratio and a 3-year bond interest rate. The weighted panel regression for 32 food sector branches and 12 years is applied.

Nekarda and Ramey (2013) distinguish three important problems connected with the measurement of labor markups. The first one concerns the included labor overheads, which consist in all activities necessary for the firm's functioning, which however cannot be connected with the products or services offered by the firm. In other words these activities do not generate profits directly. Overhead expenses include costs of accounting, advertising, insurance, legal fees, taxes, rent, repairs, telephone bills, travel expenses and utilities. The second problem is not allowing the elasticity of substitution between production factors to deviate from unity, whilst the third one concerns the usage of an average wage, which due to the overtime premium differs from the marginal wage. Accordingly, six alternative specifications will be analyzed:

1. Labor overheads

Labor input in the C-D production function excluding labor overheads is expressed as follows:

$$
(Z h N-Z \bar{h} \bar{N})^{\alpha},
$$

where $\bar{h} \bar{N}$ represents the overhead hours. Then:

$$
\mu_{A}^{C D, O H}=\frac{P}{W_{A} /\left[\alpha\left(\frac{Y}{h N-\bar{h} \bar{N}}\right)\right]}=\frac{\alpha}{s^{\prime}},
$$


where $s^{\prime}=\frac{1}{P Y} W_{A}(h N-\bar{h} \bar{N})$ is a labor share of no-overhead labor. Because Ramey (1991) advocated that the number of non-production or supervisory workers is an upper bound of overhead labor and since according to the Polish national statistics clerical support workers constitute $9,3 \%$ of all workers (CSO 2014), in the calculations as $s^{\prime}$ we took the share of $90 \%$ of costs of wages and salaries alone. Following Bils (1987) other labor payments were excluded as not increasing with the number of working hours.

2. CES production function

Allowing the elasticity of substitution between the production factors differ from unity, the production function may take the following CES form:

$$
Y=\left[\alpha(Z h N)^{\frac{\sigma-1}{\sigma}}+(1-\alpha) K^{\frac{\sigma-1}{\sigma}}\right]^{\frac{\sigma}{\sigma-1}},
$$

where $\sigma$ is the elasticity of substitution between labor and capital, and $Y$ means the value added. The markup is as follows:

$$
\mu_{A}^{C E S}=\frac{P}{W_{A} /\left[Z \alpha\left(\frac{Y}{Z h N}\right)\right]^{\frac{1}{\sigma}}}=\frac{\alpha}{s}\left(\frac{Y}{Z h N}\right)^{\frac{1}{\sigma}-1} .
$$

$\sigma$ is calculated with the $\mathrm{R}$ software (micEconCES package) taking advantage of the data for 32 food sector branches in 12 years, and value added as net revenues from the products sold adjusted by the change in inventories and indirect taxes minus costs of materials and energy. $Z$ may be extracted on three ways. The first one is based on the Solow residual series, the second on the TFP growth adjusted by utilization (Basu and Kimball 1997), in the third the structural vector autoregression (SVAR) is applied (Gali 1999, Nekarda and Ramey 2013). In this paper the first method is used.

3. CES production function and labor overheads

The above two modifications of the baseline scenario can be joined. The production function is then as follows:

$$
Y=\left[\alpha(Z h N-Z \bar{h} \bar{N})^{\sigma /(\sigma-1)}+(1-\alpha) K^{\sigma /(\sigma-1)}\right]^{\frac{\sigma}{\sigma-1}},
$$


and the markup:

$$
\begin{gathered}
\mu_{A}^{C E S, O H}=\frac{\frac{P}{W_{A}}}{Z \alpha\left(\frac{Y}{Z h N-Z \bar{h} \bar{N}}\right)^{\frac{1}{\sigma}}}=\frac{\alpha P Y}{W_{A}(h N-\bar{h} \bar{N})}\left(\frac{Y}{Z h N-Z \bar{h} \bar{N}}\right)^{\frac{1}{\sigma}-1}= \\
=\ldots=\frac{\alpha}{s^{\prime}}\left(\frac{Y}{Z h N-Z \bar{h} \bar{N}}\right)^{\frac{1}{\sigma}-1}, \\
\text { where } s^{\prime}=\frac{W_{A}(h N-\bar{h} \bar{N})}{P Y} .
\end{gathered}
$$

4. Marginal wage different from average wage

In the standard new-Keynesian literature it is assumed that the average hourly wage is an appropriate measure of marginal increase in working hours. Bils (1987) argued however that it can increase in the average working hours per worker because of the additional cost of overtime hours. Consequently, Nekarda and Ramey (2013) stated:

$$
W_{A}(h)=W_{s}\left(1+\rho \theta \frac{v(h)}{h}\right),
$$

where $W_{s}$ is a straight-time wage, $\rho$ is a premium for overtime hours, $\theta$ is a share of overtime hours commanding premium, $v / h$ is a ratio of average overtime hours to total working hours. In other words, expression $(\rho \theta v) / h$ allows the situation when companies are forced to pay a premium for overtime hours. Because in Polish statistics overtime hours are the hours commanding a premium, then $\theta=1$, whereas $\rho=50 \%$, because this is a premium for overtime hours according to the Polish Labor Code ${ }^{2}$. Consequently, the marginal cost of increasing production by increasing working hours per worker yields:

$$
M C=\frac{W_{s}\left[1+\rho \theta\left(\frac{d v}{d h}\right)\right]}{Z F_{1}(Z h N, \ldots)} .
$$

\footnotetext{
${ }^{2}$ The overtime premium for overtime hours at night, on Saturday and Sunday (not being the regular working days) amounts to $100 \%$. In the calculation it is assumed however that overtime hours are only those commanding a premium of $50 \%$.
} 
Multiplying $W_{A}$ by $\frac{W_{M}}{W_{A}}=\frac{1+\rho \theta\left(\frac{d v}{d h}\right)}{1+\rho \theta\left(\frac{v}{h}\right)}$, when the function is C-D, we get:

$$
\mu_{M}^{C D}=\frac{P}{W_{M} /\left[\alpha\left(\frac{Y}{h N}\right)\right]}=\frac{\alpha}{s\left(\frac{W_{M}}{W_{A}}\right)} .
$$

Because of the non-availability of data regarding single workers, the method applied by Nekarda and Ramey (2013) cannot be applied. The calculations were carried out based on sectorial data, although they are not so accurate due to the fact that the moments of average hours distribution are higher because all workers do not work the same average hours (Bils 1987) ${ }^{3}$.

5. CES production function together with marginal wage and labor overheads

In this specification all three adjustments are present. The markup is given by:

$$
\mu_{M}^{C E S, O H}=\frac{\alpha}{s_{M}^{\prime}}\left(\frac{Y}{Z h N-Z \bar{h} \bar{N}}\right)^{\frac{1}{\sigma}-1}
$$

where:

$$
s_{M}^{\prime}=\frac{W_{M}(h N-\bar{h} \bar{N})}{P Y}=\frac{W_{A} \frac{W_{M}}{W_{A}}(h N-\bar{h} \bar{N})}{P Y}=s^{\prime} \frac{W_{M}}{W_{A}} \text {, and } \frac{W_{M}}{W_{A}}=\frac{1+\rho \theta\left(\frac{d v}{d h}\right)}{1+\theta\left(\frac{v}{h}\right)} .
$$

${ }^{3}$ Moreover, the method proposed by Bils [1987] was performed, who in order to calculate $\mathrm{dv} / \mathrm{dh}$ used the following regression analysis:

$$
\begin{aligned}
& \Delta v_{i t}=\left\{b_{0}+b_{1} t+b_{2} t^{2}+b_{3} t^{3}+c_{1}\left[h_{i(t-1)}-40\right]+c_{2}\left[h_{i(t-1)}-40\right]^{2}+c_{3}\left[h_{i(t-1)}-40\right]^{3}\right\} \Delta h_{i t}+\ldots \\
& +a_{0}+a_{1} t+a_{2} t^{2}+a_{3} t^{3}+d_{i 1} \ln \frac{N_{i t}}{N_{i(t-1)}}+d_{i 2} \ln \frac{N_{i t}}{N_{i(t-1)}}+e_{i t},
\end{aligned}
$$

where $i$ refers to food sector branches, and $h_{t-1}$ is an average hour of previous and current years. Because of the annual data, the limit of 40 hours was substituted by annual working limits [www.kalendarzswiat.pl/wymiar_czasu_pracy]. The regression applied for the Polish data explained only 0.313 of variation in $\Delta v_{i t}$ and therefore its results were not used for further calculations. 
6. C-D production function with marginal wage and labor overheads Additionally,

$$
\mu_{M}^{C D, O H}=\frac{\alpha}{s_{M}^{\prime}},
$$

where:

$$
s_{M}^{\prime}=\frac{W_{M}(h N-\bar{h} \bar{N})}{P Y}=\frac{W_{A} \frac{W_{M}}{W_{A}}(h N-\bar{h} \bar{N})}{P Y}=s^{\prime} \frac{W_{M}}{W_{A}},
$$

and

$$
\frac{W_{M}}{W_{A}}=\frac{1+\rho \theta\left(\frac{d v}{d h}\right)}{1+\theta\left(\frac{v}{h}\right)}
$$

was calculated.

In the research annual data from the period 2002-2013 were used as reported in the SP and Z-O6 forms to the Central Statistical Office (CSO) by companies hiring more than 9 workers, or sourced from the portal www.obligacjeskarbowe.pl and other CSO official databases.

\section{BASELINE SPECIFICATION}

Table 1 presents the results of the C-D production function estimation for the baseline scenario.

Table 1

The results of production function estimation in the food sector*

\begin{tabular}{l|c|c|c}
\hline & Coefficient & Std. error & p-value \\
\hline Constant & 0.835 & 0.032 & 0.000 \\
\hline Labor costs & 0.141 & 0.005 & 0.000 \\
\hline Energy costs & 0.039 & 0.004 & 0.000 \\
\hline Materials costs & 0.782 & 0.004 & 0.000 \\
\hline Capital costs & 0.037 & 0.005 & 0.000 \\
\hline
\end{tabular}

$* R^{2}=0,999, p$-value $(F)=0.000$.

Source: own elaboration using the Polish CSO data. 
The elasticity of production with respect to labor $(\alpha=0.141)$ was then used for the markups estimation. The average food sector markup in the period analyzed amounted to 1.225 (17.68\% of price), which is similar to the results obtained by Gradzewicz and Hagemajer (2007b) for the period 1996-2004 ( $18.30 \%$ of price). Looking at the coefficient of variation, the markups proveto be more varied between branches $(0.543)$ than between years $(0.158)$. The highest markups could be observed in the production of oils and fats $(74.1 \%$ of price), malt (70.2\%), ready feed for animals $(52.7 \%)$, sugar production $(45.3 \%)$, processing and preserving of poultry (44.3\%), manufacture of ground cereal products $(41.6 \%)$, production of fruit and vegetable juices $(39.5 \%)$, processing and preservation of meat, excluding poultry $(38.2 \%)$, milk processing and production of cheese $(35.7 \%)$, production of meat preserves, including products of poultry (26.4\%), processing and preservation of fish, crustaceans and molluscs (26.4\%), production of cider and other fruit wines $(22.2 \%)$. In the remaining 14 branches out of the total of 32, on average the prices seemed lower than the marginal costs. The worst situation was in bakery products, fresh confectionary goods and cakes $(-50.5 \%)$ as well as ice cream production $(-37.1 \%)$.

The changes in the Polish food sector markups in relation to the real GDP are presented in Figure 1. Both variables are characterized by the increasing trend, but the yearly growth of markups was lower $-2.9 \%$ compared to $5.3 \%$ for the real GDP (Figure 1).

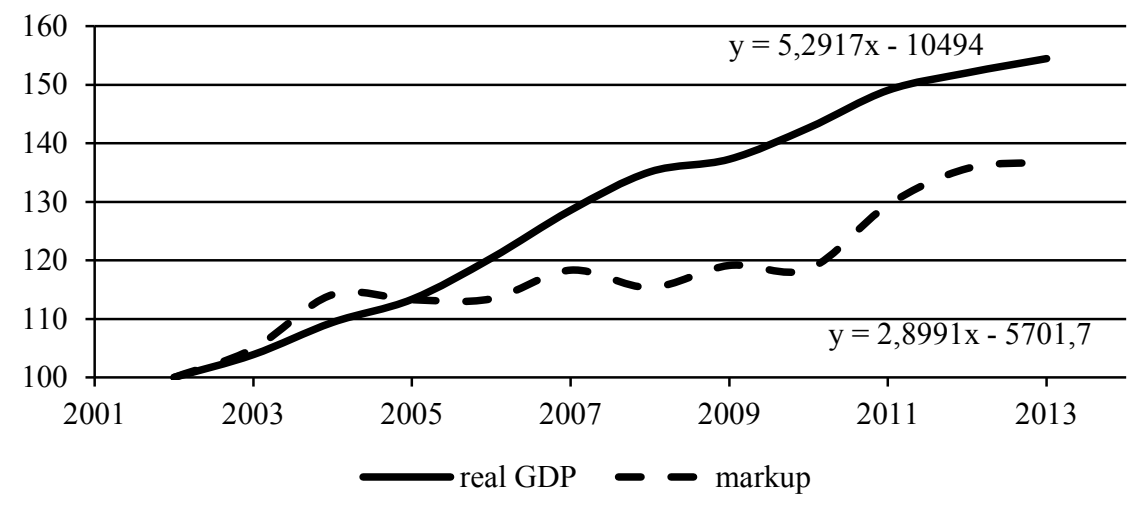

Figure 1. Markups in the Polish food sector and real GDP (2002=100) in the period 2002-2013 Source: own elaboration using the Polish CSO data. 


\section{ALTERNATIVE SPECIFICATIONS}

Table 2 summarizes the results of the baseline and alternative specifications. The mean markup in the Polish food sector in the period 20022013 differed depending on the specification from $22.7 \%$ to $67.9 \%$ of the price. The results were very sensitive to the estimation of output elasticities with respect to labor, which differ among specifications because of differences in measuring labor input and production function assumptions. The elasticities of substitution between labor and capital inputs, on the contrary, for both specifications regarding normal and no-overhead labor amounted to 0.8 , which is in line with the approximations for the Polish economy performed by Bradley et al. (2005). For their macro-model they stated that the values of the elasticity of substitution are inversely proportional to the openness of the sector measured by the share of production value exported. As in the period analyzed the Polish food sector production exported increased from 6.82 to $20.13 \%$, they would approximate it between 0.5 and 0.8 . Moreover, these authors admitted that the CES production function is not the proper one for the Polish economy because of the assumption of the constant elasticity of substitution. The more open the economy becomes, the traditional substitution of capital for labor is not present as capital prefers to change the location rather than substituting more expensive labor. Moreover, Adamczyk (2009) and Łukiewska (2014) pointed out that since in the Polish food sector marginal productivity of labor is higher, substituting capital for labor is not justified any more.

Consequently, contrary to Nekarda and Ramey (2013), we acknowledge the C-D production function with labor overheads and marginal costs as the most accurate for the estimation of the Polish food sector markups. In this specification (6), the average labor markup amounted to $48.6 \%$. It can be observed that the increase in markup by $26.3 \%$ was accompanied by the increase in the real value of production sold amounted to $62.8 \%$, which means that in the analyzed period the rapid development of the Polish food sector development has not been accompanied by a significant increase in the level of market power. The reason for this may lie in the relationship between markups and the macroeconomic business cycle. The elimination of trends gives negative correlations when using first differences or the Baxter-King filter (Table 2). When using the HP filter, the markups seemed to behave mostly a-cyclically. These results indicate that the Polish food sector behaved similarly to the whole of Polish manufacturing - pro- 
cyclically regarding the sectorial cycle and counter-cyclically in regard to the macro cycle, which is in accordance with the results obtained by Gradzewicz and Hagemajer (2007b).

Table 2

Monopolistic markups (share in price) in the food sector in different specifications

\begin{tabular}{l|c|c|c|c|c|c|c}
\hline \multirow{2}{*}{ Year } & \multicolumn{7}{|c}{ Specification } \\
\cline { 2 - 9 } & $\begin{array}{c}\text { Baseline } \\
\text { (C-D) }\end{array}$ & $\begin{array}{c}\text { 1.Over- } \\
\text { head, } \\
\text { C-D }\end{array}$ & 2.CES & $\begin{array}{c}\text { 3. CES, } \\
\text { overhead }\end{array}$ & $\begin{array}{c}\text { 4.Marginal, } \\
\text { C-D }\end{array}$ & $\begin{array}{c}\text { 5.Marginal, } \\
\text { CES, } \\
\text { overhead }\end{array}$ & $\begin{array}{c}\text { 6.Marginal, } \\
\text { C-D, } \\
\text { overhead }\end{array}$ \\
\hline$\alpha$ & 0.141 & 0.121 & 0.5 & 0.5 & 0.141 & 0.5 & 0.121 \\
\hline 2002 & 0.034 & 0.368 & 0.292 & 0.623 & 0.040 & 0.625 & 0.372 \\
\hline 2003 & 0.080 & 0.393 & 0.296 & 0.622 & -0.123 & 0.538 & 0.260 \\
\hline 2004 & 0.154 & 0.456 & 0.349 & 0.659 & 0.152 & 0.658 & 0.454 \\
\hline 2005 & 0.148 & 0.453 & 0.360 & 0.665 & 0.180 & 0.678 & 0.474 \\
\hline 2006 & 0.149 & 0.451 & 0.377 & 0.673 & 0.234 & 0.706 & 0.506 \\
\hline 2008 & 0.184 & 0.462 & 0.395 & 0.677 & 0.068 & 0.630 & 0.386 \\
\hline 2009 & 0.163 & 0.429 & 0.367 & 0.650 & 0.295 & 0.705 & 0.519 \\
\hline 2010 & 0.189 & 0.446 & 0.421 & 0.679 & 0.849 & 0.940 & 0.897 \\
\hline 2011 & 0.185 & 0.443 & 0.399 & 0.666 & 0.186 & 0.666 & 0.444 \\
\hline 2013 & 0.254 & 0.490 & 0.394 & 0.663 & 0.255 & 0.663 & 0.491 \\
\hline Mean & 0.288 & 0.517 & 0.392 & 0.664 & 0.288 & 0.664 & 0.517 \\
\hline Var. coeff. & 0.294 & 0.515 & 0.412 & 0.671 & 0.297 & 0.672 & 0.517 \\
\hline Change in -ln(s) & 0.177 & 0.452 & 0.371 & 0.659 & 0.227 & 0.679 & 0.486 \\
\hline & 0.077 & 0.044 & 0.042 & 0.019 & 0.232 & 0.093 & 0.151 \\
\hline HP filter & 0.313 & 0.265 & 0.185 & 0.137 & 0.312 & 0.135 & 0.263 \\
\hline Faxter-King filter & 0.217 & 0.146 & -0.299 & -0.281 & -0.429 & -0.447 & -0.429 \\
\hline
\end{tabular}

Source: own elaboration using the Polish CSO data.

\section{CONCLUSIONS AND RECOMMENDATIONS}

The research objective was to measure labor markups in the Polish food sector in the period 2002-2013 using updated empirical methods and data proposed by Nekarda and Ramey (2013). The developments regarding labor overheads, CES production function and marginal wage not equal to average wage were considered, as well as some adjustments due to the availability of Polish statistics, were performed. The average markup amounted to $17.7 \%$ of price in a baseline specification, and was higher in alternative specifications, reaching $67.9 \%$ when CES, labor overheads and marginal wage were included. It appeared that the results are highly sensitive to the estimation of 
parameters in C-D and CES production functions, as to the assumptions taken by these functions. Therefore, the future research direction should focus on using standard log-linear approximations around a steady state described by Gali et al. (2007) for labor markups estimation, as well as on labor adjustment costs, labor hoarding and variable capital utilization during markup estimation, as proposed by Rotemberg and Woodford (1999]. Confirming the obtained high markups estimates with further methods and data will mean the significant deviation from perfect competition, which indicate the need for a better competition policy for the sector.

Moreover, regarding the business cycle, the Polish food sector markups appeared to behave according to the same pattern as the markups in the whole of the manufacturing, therefore, further analysis of this relationship with VAR models, regressions with instrumental variables, and cross correlations can be run in order to check whether food sector markups are a good leading indicator for business cycle changes.

\section{REFERENCES}

Adamczyk, P., Substytucyjność czynników produkcji w przemyśle spożywczym w Polsce [The Production Factors Substitution in the Food Industry in Poland], „Scientific Journal of Warsaw University of Life Science-SGGW - Economics and Organization of Agri-Food Sector, no. 79, pp. 111-123, 2009.

Basu, S., Kimball, M., Cyclical Productivity with Unobserved Input Variation, National Bureau for Economic Research Technical Working Paper, no. 5915, Cambridge, 1997.

Bils, M., The Cyclical Behavior of Marginal Cost and Price, "American Economic Review", no. 77(5), pp. 837-873, 1987.

Bradley, J., Zaleski, J., Tomaszewski, P., Modyfikacja ekonometrycznego modelu HERMIN do oceny wptywu funduszy strukturalnych na polska gospodarke i opracowania modelu dla polskich regionów województw [Modification of Econometric Model HERMIN Used for Evaluation of Structural Funds Impact on Polish Economy and Development of Model for Polish Regions]. WARR, Wrocław, 2005.

Carlton, D., Perloff, J., Modern Industrial Organization. Person, Addison, Wesley, Boston, 2005.

Church, J., Ware, R., Industrial Organization: A Strategic Approach. Irwin McGraw-Hill, Boston, 2000.

CSO, Maty Rocznik Statystyczny [Concise Statistical Yearbook]. Central Statistical Office, Warsaw, 2014.

Gali, J., Technology, Employment, and the Business Cycle: Do Technology Shocks Explain Aggregate Fluctuations?, “American Economic Review”, no. 89(1), pp. 249-71, 1999.

Galí, J., Gertler, M., López-Salido, J., Markups, Gaps, and the Welfare Costs of Business Fluctuations, "Review of Economics and Statistics", no. 89(1), pp. 44-59, 2007. 
Gradzewicz, M., Growiec, J., Wyszyński, R., Luka nieefektywności w cyklu koniunkturalnym $w$ Polsce [The Inefficiency Gap in the Business Cycle in Poland], National Bank of Poland, pp. 1-35, 2012.

Gradzewicz, M., Hagemejer, J., Marże monopolistyczne i przychody skali w gospodarce polskiej - Analiza mikroekonomiczna [Monopolistic Markups and Returns to Scale in the Polish Economy], „Ekonomista”, pp. 515-540, 2007 a.

Gradzewicz, M., Hagemejer, J., Wptyw konkurencji oraz cyklu koniunkturalnego na zachowanie się marz monopolistycznych $w$ gospodarce polskiej [Impact of Competition and Business Cycles on the Behaviour of Monopolistic Markups in the Polish Economy], „Bank i Kredyt”, no. 1, 2007b.

Hagemejer, J., Popowski, P., The Distribution of Monopolistic Markups in the Polish Economy, National Bank of Poland Working Papers, no. 121, 2012.

Łopaciuk, W., Wasilewski, A., Wigier, M., Food Economy and Rural Areas in PolandStructural Changes and Effectiveness of Public Policy. IAFE-NRI, Warsaw, 2014.

Łukiewska, K., Produktywność w przemyśle spożywczym w Polsce - poziom i międzybranżowe zróżnicowanie [Productivity in Food Industry in Poland], „Annals of Agricultural Economics and Rural Development", vol. 101, no. 1, pp. 53-63, 2014.

Nekarda, C., Ramey, V., The Cyclical Behavior of the Price-Cost Markup, NBER Working Paper, Washington, 2013.

Pindyck, R., Rubinfeld ,D., Microeconomics. Pearson, New Jersey, 2013.

Ramey, V., Discussion of Markups and the Business Cycle [in:] Blanchard, O., Fischer, S. (eds.), NBER Macroeconomics Annual, MIT Press, pp. 134-140, 1991.

Roeger, W., Can Imperfect Competition Explain the Difference between Primal and Dual Productivity Measures? Estimates for US Manufacturing, "Journal of Political Economy", 103(2), pp. 316-330, 1995.

Rotemberg, J., Woodford, M., The Cyclical Behavior of Prices and Costs [in:] Taylor, J., Woodford, M. (eds.), Handbook of Macroeconomics. Elsevier, Amsterdam, 1999.

Samuelson,W., Marks, S., Ekonomia menadżerska [Managerial Economics]. PWE, Warsaw, 2009.

Szczepaniak, I., Struktura podmiotowa przemystu spożywczego [Subject Structure of Food Industry] [in:] Mroczek, R. (ed.), Procesy dostosowawcze polskiego przemystu spożywczego do zmieniajacego się otoczenia rynkowego (2) [Adjustment Processes of Polish Food Industry to the Changing Market Environment]. IAFE-NRI, Warsaw, 2012.

The Royal Swedish Academy of Sciences, Jean Tirole: Market Power and Regulation. Scientific Background on the Sveriges Riksbank Prize in Economic Sciences in Memory of Alfred Nobel 2014, Stockholm, 2014.

Tremblay, V., Tremblay, C., New Perspective on Industrial Organization with Contributions from Behavioral Economics and Game Theory. Springer, New York, 2012.

www.kalendarzswiat.pl/wymiar_czasu_pracy (01.05.2015).

www.obligacjeskarbowe.pl (01.05.2015).

Received: September 2015, revised: March 2018 